\title{
Characteristics of polypoidal choroidal vasculopathy in the Malaysian population
}

Rona Asnida Nasaruddin ${ }^{1}$, Wong Hon Seng ${ }^{2}$, Amelia Lim Lay Suan ${ }^{3}$, Norshamsiah Md Din $^{1}$, Mae-Lynn Catherine Bastion ${ }^{1}$

${ }^{1}$ Department of Ophthalmology, Hospital Canselor Tuanku Muhriz, Universiti Kebangsaan Malaysia Medical Centre (UKMMC), Cheras, Kuala Lumpur, Malaysia; ${ }^{2}$ Ophthalmology, Gleneagles Hospital and Oasis Eye Centre, Kuala Lumpur, Malaysia; ${ }^{3}$ Hospital Kuala Lumpur, Ministry of Health Malaysia, Kuala Lumpur, Malaysia

\section{Abstract}

Introduction: Polypoidal choroidal vasculopathy (PCV) is a distinct clinical entity, characterized by focal hyperfluorescence in the early phase of indocyanine green angiography (ICGA), with or without its associated branching vascular network (BVN).

Purpose: To report the angiographic characteristics of PCV on ICGA in presumed PCV patients.

Study design: Descriptive cross-sectional study.

Materials and methods: This study involved 36 suspected PCV patients who attended the Ophthalmology Clinic, Universiti Kebangsaan Malaysia Medical Centre from June 1, 2012 to May 31, 2013. All patients underwent complete ophthalmologic examination including colour fundus photography, ICGA, and fundus fluorescein angiography. ICGA images of confirmed PCV patients were analysed. Results: Twenty-five out of 36 eyes (69.4\%) were diagnosed to have PCV based on ICGA. Mean age of confirmed PCV patients was $66.4 \pm 8.42$ years, with predominance of males $(n=17)$ and Chinese ethnicity $(n=19)$. Best-corrected visual acuity (BCVA) was between $6 / 6$ and $6 / 18$ in $64 \%$. All 25 patients had unilateral disease. Average size of PCV lesions was $1461.4 \pm 864.4 \mu \mathrm{m}$. The lesions were mostly concentrated in the extrafoveal region $(n=15,60 \%)$. Lesion formation was cluster

Correspondence: Prof. Dr. Mae-Lynn Catherine Bastion, FRCSG (UK), DrOphth (UKM), Department of Ophthalmology, Pusat Perubatan UKM, Jalan Yaacob Latif, 56000, Cheras, Kuala Lumpur, Malaysia.

E-mail:mae-lynn@ppukm.ukm.edu.my 
in $56 \%(n=14)$, single in $32 \%(n=8)$, string in $4 \%(n=1)$, and combination in $8 \%$ $(n=2)$. The majority involved a single discrete area. Polyp pulsation was detected in six eyes, while seven eyes revealed nodular hyperfluorescence when viewed stereoscopically. BVN was evident in 56\% $(n=14)$. Fifteen eyes demonstrated the hypofluorescent halo, while no hyperfluorescent ring was seen in this study population. Late geographical hyperfluorescence (LGH) was noted in seven eyes $(28 \%)$. There was no significant association between the morphological characteristics of PCV, i.e., size of lesion, location, formation, discrete area involved, and LGH with BCVA.

Conclusion: The demographic, clinical, and angiographic features observed in this study were in agreement with other previously published Asian studies. However, we found no association between the morphological characteristics of PCV with BCVA.

Keywords: branching vascular network, focal hyperfluorescence, indocyanine green angiography, polypoidal choroidal vasculopathy

\section{Abstrak}

Pengenalan: Penyakit "polypoidal choroidal vasculopathy" (PCV) merupakan entiti klinikal yang unik, bercirikan hiperfluoresen tertumpu yang dilihat pada fasa awal angiografi "indocyanine green" (ICGA), dengan atau tanpa rangkaian vaskular bercabang (“branching vascular network” (BVN)).

Tujuan: Untuk melaporkan ciri-ciri penyakit PCV dengan mengkaji imej-imej ICGA pesakit yang disyaki menghidapi PCV.

Reka bentuk kajian: Kajian keratan rentas deskriptif.

Metodologi: Kajian ini bermula dari 1 Jun 2012 hingga 31 Mei 2013 dan melibatkan 36 orang pesakit yang disyaki menghidapi PCV dari Klinik Oftalmologi, Pusat Perubatan Universiti Kebangsaan Malaysia. Para pesakit menjalani pemeriksaan mata komprehensif, termasuk pengambilan gambar fundus, ICGA dan angiografi "fundus fluorescein". Imej-imej ICGA yang telah disahkan sebagai penyakit PCV telah dianalisa.

Keputusan: Dua puluh lima dari 36 mata (69.4\%) disahkan sebagai PCV berdasarkan analisa ICGA. Purata umur ialah $66.4 \pm 8.42$ tahun, dengan majoritinya lelaki $(n=$ 17) dan kaum Cina $(n=19)$. $64 \%$ mempunyai tahap penglihatan $6 / 6$ sehingga $6 / 18$. Kesemua 25 pesakit mengalami PCV pada sebelah mata sahaja. Purata saiz PCV ialah $1461.4 \pm 864.4 \mu \mathrm{m}$. Kebanyakan PCV ditemui pada kawasan "extrafoveal" $(n=15,60 \%)$. Pembentukan PCV adalah berkelompok 56\% $(n=14)$, tunggal $32 \%(\mathrm{n}=8)$, menyerupai "tali" $4 \%(n=1)$ dan kombinasi $8 \%(n=2)$. Majoriti PCV ditemui di dalam satu kawasan sahaja. 6 mata dikesan mempunyai polip berdenyut, sementara 7 mata mempamerkan "nodular hyperfluorescence" apabila 
dilihat secara stereoskopik. BVN jelas kelihatan pada 56\% mata $(n=14) .15$ mata menunjukkan "hypofluorescent halo", sementara tiada "hyperfluorescent ring" dikesan. "Late geographical hyperfluorescence" (LGH) diperhatikan pada 7 mata (28\%).

Tiada kaitan yang signifikan di antara ciri-ciri morfologi penyakit PCV seperti saiz lesi, lokasi, pembentukan, kawasan yang terlibat, LGH dengan tahap penglihatan.

Kesimpulan: Data demografi, ciri klinikal serta ciri-ciri ICGA di dalam kajian ini mempunyai persamaan dengan kajian-kajian terdahulu yang melibatkan penduduk negara-negara Asia yang lain. Ciri-ciri morfologi PCV tidak mempengaruhi tahap penglihatan.

Kata kekunci: rangkaian vaskular bercabang, fokus hiperfluoresen, angiografi "indocyanine green", "polypoidal choroidal vasculopathy"

\section{Introduction}

Polypoidal choroidal vasculopathy (PCV) is a distinct clinical entity characterized by focal hyperfluorescence in the early phase of indocyanine green angiography (ICGA), with or without its associated branching vascular network (BVN). ${ }^{1}$ The clinical findings of PCV vary considerably, thus raising a diagnostic dilemma. There is significant overlap between the retinal manifestations of this disease with exudative age-related macular degeneration (AMD). ${ }^{2-4}$ Some authorities consider PCV as a variant of neovascular AMD. ${ }^{5}$ However, the natural history and visual prognosis of PCV are more favourable. ${ }^{6-8}$ On the other hand, others regard it as a different disease entirely. ${ }^{6,9}$ Published studies from Asian countries quote that the proportion of PCV among eyes with exudative AMD ranges from 9.3-55\%, , $^{5,-12}$ while data from Caucasian populations revealed that the PCV prevalence among exudative AMD patients is $7.8-12 \%,{ }^{4,13-15}$

The knowledge on PCV is rapidly evolving as the work is still ongoing. Based on the fact that PCV may mimic other acquired macular disorders, this study was undertaken to describe the diverse clinical and angiographic manifestations of this peculiar disease, specifically in presumed PCV patients attending the Ophthalmology Clinic, Universiti Kebangsaan Malaysia (UKM) Medical Centre. It is imperative to clarify the demographic features of PCV, together with its clinical and angiographic characteristics, so that the optimal management can be established for the patients.

The aims of this study were to determine the prevalence of PCV in presumed PCV patients, to describe the angiographic characteristics in confirmed PCV patients, and to determine the association between the morphological characteristics of PCV and best-corrected visual acuity (BCVA). 


\section{Materials and methods}

This cross-sectional study was conducted from June 1, 2012 to May 31, 2013 at the Ophthalmology Clinic, UKM Medical Centre, Kuala Lumpur, Malaysia. Ethics approval from the Research and Ethics Committee, Faculty of Medicine, Universiti Kebangsaan Malaysia (FF-156-2012) and National Medical Research Register of the Ministry of Health Malaysia were obtained prior to commencement of the study. The study followed the guidelines set in the Malaysian Good Clinical Practice (2nd edition, January 2004) and was conducted in accordance to the principles of the Declaration of Helsinki.

The inclusion criteria for the study were patients $\geq 50$ years old with suspected PCV features on fundoscopy and fundoscopic examination revealing serosanguineous maculopathy with one of the distinctive features of visible, orange-red subretinal nodules, serous, serosanguineous, or notched retinal pigment epithelial detachment (PED), chronic or multifocal central serous chorioretinopathy (CSCR), massive submacular haemorrhage, or breakthrough bleeding into the vitreous. Patients were excluded from the study if they had diabetic maculopathy, maculopathy secondary to central or branch retinal vein occlusion, pathological myopia, angioid streaks, presumed ocular histoplasmosis syndrome, significant media opacities preventing adequate fundus examination and photography, history of ocular trauma, previous panretinal laser photocoagulation, known allergy towards sodium fluorescein or indocyanine green dyes, and did not consent to ICGA and fundus fluorescein angiography (FFA).

Patients who fulfilled the inclusion criteria were identified and recruited into the study. The nature and purpose of the study were explained in detail to all participants by the investigator and provided in an information sheet. Informed consent was obtained from those who agreed to participate. Consecutive, universal sampling of patients was employed in this study.

A digital colour fundus photograph of the macular region (50 angles of coverage) was acquired using a Topcon TRC-50DX (Type IA) retinal camera (Topcon, Tokyo, Japan). Optical coherence tomography (OCT) was performed using a Spectralis OCT (Heidelberg Engineering, Dossenheim, Germany).

For the ICGA, $25 \mathrm{mg}$ of indocyanine green molecules dissolved in $5 \mathrm{ml}$ of sterile water for injection was injected into the cubital vein. Dynamic high-speed ICGA using the Heidelberg Retinal Angiograph 2 (HRA2) (Heidelberg Engineering, Dossenheim, Germany) was recorded for the first 30 seconds, while still frames were acquired at 1, 2, 5, 10, 15, and 30 minutes. Stereo pairs were also captured.

FFA was also performed using the HRA2 after completion of ICGA. The procedure required the intravenous injection of $5 \mathrm{ml}$ of $10 \%$ sodium fluorescein solution through the existing brannula. Angiography commenced in 10 to 12 seconds, following quick (less than 6 seconds) fluorescein injection. A video during the filling phase was captured. Images of the macula were further obtained at approx- 
imately $30,60,90$, and 180 seconds post-injection. Late-phase photos were taken between 5 and 10 minutes post-injection.

The angiograms were evaluated independently by a medical retina specialist (WHS) and the investigator (RAN). Once the diagnosis of PCV was confirmed, the ICGA images were analysed by the investigator. The lesions were analysed according to size of polyp, location, formation, and number of discrete polyp areas. After this preliminary analysis, two medical retina specialists (WHS and ALLS) reviewed the angiograms again to correlate the ICGA findings with the FFA findings. The following features were noted on FFA: blocked fluorescence and choroidal neovascular membrane (CNV) characteristics; namely, classic, predominantly classic, minimally classic, and occult. ${ }^{16}$ The following features were noted on ICGA: interconnecting channels (ICC), BVN with late leakage, and absence of leakage. ICC was defined as a criss-crossed network which fills up simultaneously during the choroidal phase and has no specific direction of flow or point of origin. ${ }^{17}$ BVN was defined as a vascular network that shows a unidirectional flow or a point of origin which fans out to the periphery to supply terminal polyps. ${ }^{17}$

PCV is defined as the presence of hyperfluorescence or hot spot (polyp) occurring early in the ICGA which persisted into the late stage, with at least one of the clinical or angiographic criteria being met (a dark halo surrounding it, pulsation in the polyp, presence of ICC or BVN, nodular appearance on stereoscopic view, orange subretinal nodules on colour fundus photograph, or presence of massive submacular haemorrhage of at least four disc areas). ${ }^{1}$ Presence or absence of dye leakage was documented, and the source of leakage -either from BVN, polyps, or both- was identified.

To minimize errors, all funduscopic examinations were performed by the principal investigator (RAN); digital colour fundus photography, OCT, ICGA, and FFA were performed by a single trained staff; and independent interpretation of the angiograms were conducted by the investigator and a medical retina specialist.

The raw data were tabulated using Microsoft Office Excel 2007. The keyed in data were checked for entry errors and inconsistencies. The data was analysed using Statistical Package for Social Sciences (SPSS) Statistics 22. Kolmogorov-Smirnov test was used to test the normality of the distribution. The independent samples T-test was employed to analyse continuous variables against categorical data. Pearson's Chi-square test was utilised to look for any association between morphological characteristics and BCVA. A $P$-value of less than 0.05 was considered significant. Correlation analyses were performed to look for correlations between the CNV type (classic and occult) and blocked fluorescence seen on FFA, and late leakage from the BVN on ICGA with PCV. 
Table 1. Characteristics of visual symptoms

\begin{tabular}{|l|l|}
\hline $\begin{array}{l}\text { Eye affected } \\
\text { Right } \\
\text { Left }\end{array}$ & Number of patients, $\boldsymbol{n = 3 6} \mathbf{( \% )}$ \\
\hline $\begin{array}{l}\text { Symptoms } \\
\text { Asymptomatic }\end{array}$ & $22(61.1)$ \\
$\quad$ Blurring of vision & $14(38.9)$ \\
Central scotoma & $8(22.2)$ \\
Metamorphopsia & $14(38.9)$ \\
Floaters & $7(19.4)$ \\
\hline Duration & $0(0.0)$ \\
$<1$ month & \\
$1-12$ months & $4(14.3)$ \\
$>12$ months & $17(60.7)$ \\
\hline Best-corrected visual acuity & $7(25.0)$ \\
$6 / 6-6 / 18$ & $24(6.7)$ \\
$<6 / 18-6 / 60$ & $6(16.7)$ \\
$<6 / 60$ & $6(16.7)$ \\
\hline
\end{tabular}

\section{Results}

From June 1, 2012 to May, 31 2013, 36 patients (36 eyes) who fulfilled the study inclusion criteria were included in the study (Table 1); from this group only 25 eyes had confirmed PCV. The age of the PCV patients ranged from 50 to 84 years old, with a mean age of $66.4 \pm 8.42$ years. Seventeen (68.0\%) were men and $8(32.0 \%)$ were women. Chinese ethnicity was predominant in this group with $76.0 \%$, while $48.0 \%$ were active and ex-smokers. Sixteen (64.0\%) patients had a BCVA between $6 / 6$ and 6/18, with the remainder having a BCVA worse than 6/18 (Table 2).

The non-PCV patients were diagnosed with exudative AMD $(n=6)$, retinal angiomatous proliferation (RAP) $(n=1), \operatorname{CSCR}(n=1), \operatorname{PED}(n=1)$, and diabetic macular oedema $(n=1)$. One patient had a massive subretinal bleed, rendering the ICGA and FFA images inconclusive.

The right eye was affected in $60 \%$ of the PCV group. Forty percent complained of blurred vision, while $20 \%$ noted a central scotoma, another $20 \%$ had metamorphopsia, and the rest were asymptomatic. No patients had floaters. The duration of symptoms ranged from 1 week to 5 years.

A total of 12 eyes had PED: 3 haemorrhagic, 3 large, and the remainder serous. Ten out of 16 eyes had exudation on fundoscopy. Subretinal nodules were observed in 
Table 2. Demographic data of PCV patients

\begin{tabular}{|l|l|}
\hline Characteristics & $\boldsymbol{n}(\%)$ \\
\hline Mean age (years \pm SD) & $66.4 \pm 8.42$ \\
\hline $\begin{array}{l}\text { Gender } \\
\text { Female } \\
\text { Male }\end{array}$ & $8(32.0)$ \\
\hline $\begin{array}{l}\text { Ethnicity } \\
\text { Malay } \\
\text { Chinese }\end{array}$ & $17(68.0)$ \\
\hline $\begin{array}{l}\text { Smoking status } \\
\text { Active } \\
\text { Ex-smoker } \\
\text { Non-smoker }\end{array}$ & $6(24.0)$ \\
\hline $\begin{array}{l}\text { Best-corrected visual acuity } \\
6 / 6-6 / 18 \\
<6 / 18\end{array}$ & $19(76.0)$ \\
\hline
\end{tabular}

only two eyes, while only one eye presented with massive submacular haemorrhage. Nine eyes were noted to have subretinal/subretinal pigment epithelium (RPE) fluid and subretinal bleed. Only one eye had an ipsilateral macular scar. Age-related maculopathy (ARM) was documented in 14 fellow eyes (Table 3).

The size of PCV lesions measured as the greatest linear dimension (GLD) ranged from 223 to $3625 \mu \mathrm{m}$, with an average mean of $1461.4 \pm 864.4 \mu \mathrm{m}$. More than half the PCV lesions ( $n=15,60 \%$ ) were concentrated in the extrafoveal region, the majority of which involved a single discrete area. As for the formation of lesions, 56\% $(n=$ 14) were in clusters, followed by single formation at $32 \%$. Only six eyes were found to have pulsating polyps on dynamic ICGA, while nodular hyperfluorescence when viewed stereoscopically was only seen in seven cases. BVN was evident in $56 \%$ ( $n$ $=14$ ). Fifteen patients demonstrated the hypofluorescent halo surrounding the polyp, while no hyperfluorescent ring was seen in any case. PED was present in seven $(28 \%)$ patients. Late geographical hyperfluorescence (LGH) was demonstrated in seven eyes (28\%) (Table 4).

There was no significant difference noted in the mean size of PCV lesions between the two BCVA groups, $P=0.232$ (Table 5). Further analysis of PCV lesion characteristics did not reveal any statistically significant association between BCVA and morphological characteristics of said lesions, $P>0.05$ (Tables $6-9$ ).

Twelve $(48 \%)$ of the PCV patients were active smokers or ex-smokers. There was no statistically significant association found between smoking and PCV (Chi-square test, $P=0.271)$. 
Table 3. Retinal manifestations of PCV patients

\begin{tabular}{|c|c|}
\hline Funduscopic findings & Number of eyes, $n$ \\
\hline Subretinal nodule & 2 \\
\hline $\begin{array}{l}\text { PED } \\
\qquad \begin{array}{l}\text { Large } \\
\text { Serous } \\
\text { Haemorrhagic }\end{array}\end{array}$ & $\begin{array}{l}12 \\
3 \\
6 \\
3 \\
\end{array}$ \\
\hline $\begin{array}{l}\text { Massive submacular } \\
\text { haemorrhage }\end{array}$ & 1 \\
\hline Exudation & 10 \\
\hline Subretinal bleed & 5 \\
\hline Subretinal/sub-RPE fluid & 4 \\
\hline Intraretinal haemorrhage & 3 \\
\hline $\begin{array}{c}\text { Drusen } \\
\text { Hard } \\
\text { Soft }\end{array}$ & $\begin{array}{l}4 \\
1\end{array}$ \\
\hline Macular scar & 1 \\
\hline ARM in fellow eye & 14 \\
\hline
\end{tabular}

PCV: polypoidal choroidal vasculopathy; PED: retinal pigment epithelium detachment; RPE: retinal pigment epithelium; ARM: age-related maculopathy

Table 5. Association between BCVA and size of PCV lesions

\begin{tabular}{|l|l|l|}
\hline BCVA & $\begin{array}{l}\text { Size of PCV lesions } \\
(\mathbf{m e a n}(\mathbf{S D}))(\boldsymbol{\mu m})\end{array}$ & P-value \\
\hline $6 / 6-6 / 18$ & $1308.14(770.58)$ & \multirow{2}{*}{$0.232^{\mathrm{a}}$} \\
\hline$<6 / 18-$ CF & $1783.2(1000.61)$ & \\
\hline
\end{tabular}

BCVA: best-corrected visual acuity; PCV: polypoidal choroidal vasculopathy; CF: counting fingers

andependent samples T-test, $P<0.05$ 
Table 4. Indocyanine green angiography characteristics in confirmed PCV patients $(n=25)$

\begin{tabular}{|c|c|c|}
\hline ICGA characteristics & Frequency & Percentage (\%) \\
\hline $\begin{array}{l}\text { Location } \\
\text { Subfoveal } \\
\text { Juxtafoveal } \\
\text { Extrafoveal } \\
\text { Peripapillary } \\
\text { Combination }\end{array}$ & $\begin{array}{l}6 \\
1 \\
15 \\
2 \\
1 \\
\end{array}$ & $\begin{array}{l}23 \\
4 \\
60 \\
8 \\
4\end{array}$ \\
\hline $\begin{array}{c}\text { Area involved } \\
\text { Single } \\
\text { Multiple }\end{array}$ & $\begin{array}{l}25 \\
5\end{array}$ & $\begin{array}{l}80 \\
20\end{array}$ \\
\hline $\begin{array}{l}\text { Formation } \\
\text { Single } \\
\text { Cluster } \\
\text { String } \\
\text { Combination }\end{array}$ & $\begin{array}{l}8 \\
14 \\
1 \\
2 \\
\end{array}$ & $\begin{array}{l}32 \\
56 \\
4 \\
8 \\
\end{array}$ \\
\hline Pulsation of polyp & 6 & 24 \\
\hline $\begin{array}{l}\text { Leakage on ICGA } \\
\text { Polyp } \\
\text { BVN } \\
\text { Both }\end{array}$ & $\begin{array}{l}9 \\
5 \\
1 \\
3\end{array}$ & 36 \\
\hline Nodular lesion & 7 & 28 \\
\hline BVN & 14 & 56 \\
\hline Hypofluorescent halo & 15 & 60 \\
\hline Hyperfluorescent ring & 0 & 0 \\
\hline PED & 7 & 28 \\
\hline LGH & 7 & 28 \\
\hline
\end{tabular}

PCV: polypoidal choroidal vasculopathy; ICGA: indocyanine green angiography; BVN: branching vascular network PED: retinal pigment epithelium detachment; LGH: late geographical hyperfluorescence 

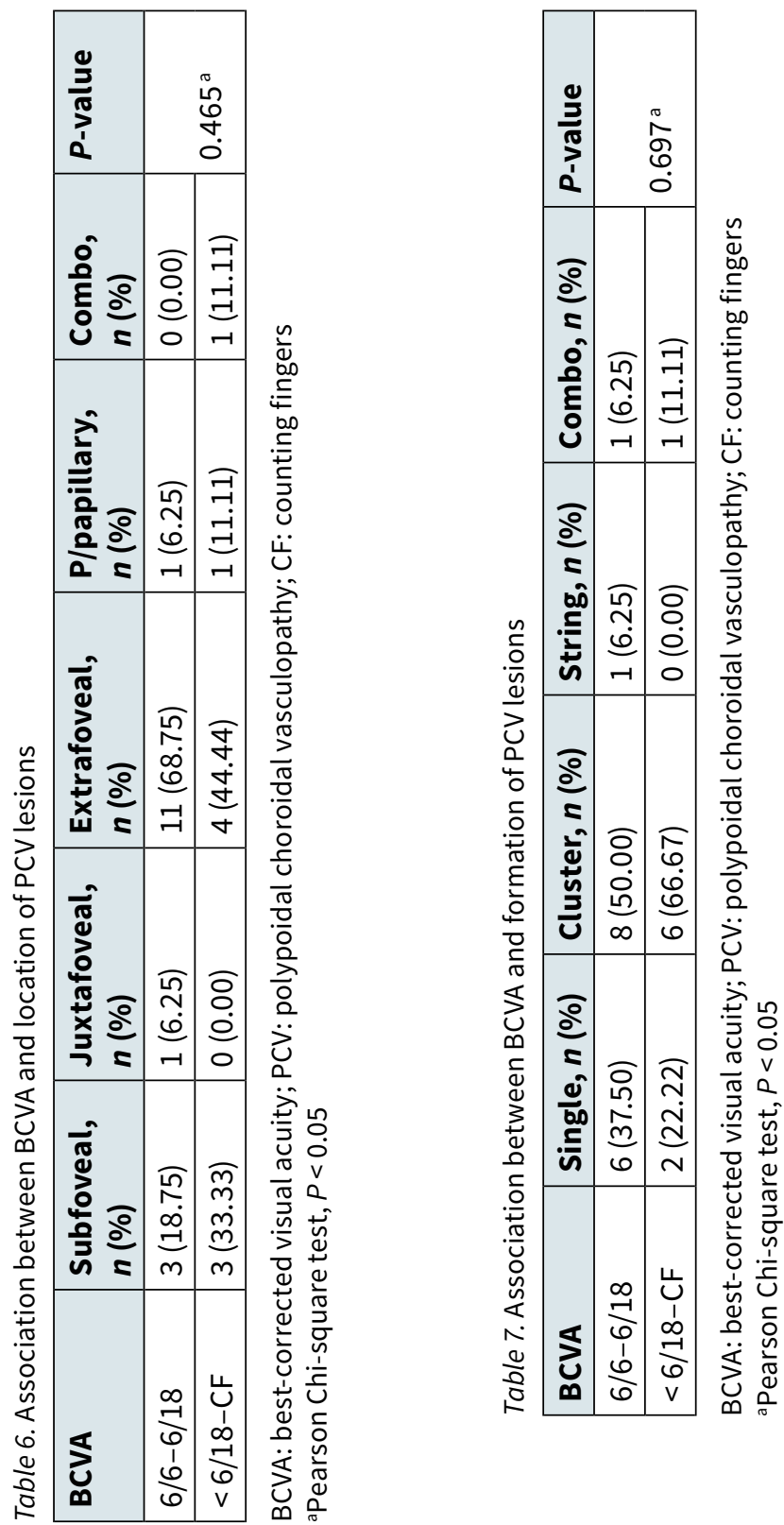
Table 8. Association between BCVA and number of discrete PCV areas

\begin{tabular}{|l|l|l|l|}
\hline BCVA & $\begin{array}{l}\text { Single, } \boldsymbol{n} \\
(\%)\end{array}$ & $\begin{array}{l}\text { Multiple, } \boldsymbol{n} \\
(\%)\end{array}$ & P-value \\
\hline $6 / 6-6 / 18$ & $12(75.00)$ & $4(25.00)$ & \multirow{2}{*}{$0.405^{a}$} \\
\hline$<6 / 18-$ CF & $8(88.89)$ & $1(11.11)$ & \\
\hline
\end{tabular}

BCVA: best-corrected visual acuity; PCV: polypoidal choroidal vasculopathy; CF: counting fingers

apearson Chi-square test, $P<0.05$

Table 9. Association between BCVA and late geographical hyperfluorescence (LGH)

\begin{tabular}{|l|l|l|l|}
\hline BCVA & $\begin{array}{l}\text { LGH } \\
\text { present, } \\
\boldsymbol{n}(\%)\end{array}$ & $\begin{array}{l}\text { No LGH, } \\
\boldsymbol{n}(\%)\end{array}$ & P-value \\
\hline $6 / 6-6 / 18$ & $5(31.25)$ & $11(68.75)$ & $0.629^{a}$ \\
\hline$<6 / 18-$ CF & $2(22.22)$ & $7(77.78)$ & \\
\hline
\end{tabular}

BCVA: best-corrected visual acuity; LGH: late geographical hyperfluorescence; CF: counting fingers

aPearson Chi-square test, $P<0.05$

Table 10. FFA findings in PCV and non-PCV patients

\begin{tabular}{|l|l|l|}
\hline FFA findings & $\mathbf{P C V}, \boldsymbol{n}(\%)$ & Non-PCV, $\boldsymbol{n}(\%)$ \\
\hline Blocked fluorescence & $4(16.0)$ & 2 (data not available for 8 eyes) \\
\hline Classic CNV lesion & $1(4.0)$ & $0(0.0)$ \\
\hline Predominantly classic CNV lesion & $3(12.0)$ & $2(28.6)$ \\
\hline Minimally classic CNV lesion & $9(36.0)$ & $1(14.3)$ \\
\hline Occult CNV lesion & $11(44.0)$ & $4(57.1)$ \\
\hline
\end{tabular}

FFA: fundus fluorescein angiography; PCV: polypoidal choroidal vasculopathy; CNV: choroidal neovascularization 
Table 10 documents the type of CNV found in PCV patients on FFA. The majority of PCV patients show minimally classic and occult CNV lesions on FFA. We found that $11(44 \%)$ and $14(56 \%)$ of PCV patients had ICC and BVN on their ICGA images, respectively. Eight (57.1\%) out of 14 eyes with BVN demonstrated late leakage on FFA. In particular, the type of CNV on FFA with the ICGA features of BVN with late leakage was investigated. There was no significant correlation between the two parameters, (correlation coefficient, $\rho=-0.39, P=0.15$ ). There was also no significant association as tested with logistic regression analysis between the two variables, $p=0.154$.

\section{Discussion}

The prevalence of presumed PCV in our study is $69.4 \%$. This is high compared to previous Asian studies, which quote the proportion of PCV in patients with features of exudative AMD in the range of 9.3-55\%.5,6,10-12 On the other hand, the prevalence of exudative AMD in Caucasians ranges from 7.8-12\%.,13,15 Our prevalence is high owing to the fact that we included patients who we presumed to have PCV. As a matter of fact, the prevalence should be even higher than our current results, as we included patients who presented with known clinical features of PCV, namely, presence of orange subretinal nodule, serous, serosanguineous, or notched PED, massive submacular haemorrhage, and CSCR-like features. ${ }^{16}$ The less than expected prevalence highlights the fact that other acquired macular diseases may mimic PCV.

The average mean age of PCV patients in our study population was 66.96 years, which is similar to other studies conducted in Asian countries. Men were more likely to be affected than women by a 2:1 ratio, which also seems to be in accordance to other studies carried out in Japan, Korea, and China..$^{5-6,12}$ In whites, there is female predominance. ${ }^{9}$ There was a majority of Chinese patients in our study, which can be attributed to the fact that Cheras and areas nearby Kuala Lumpur, catered by our institution, are densely populated by this ethnic group.

The presence of orange subretinal nodular structures associated with an adjacent serous PED or a neurosensory detachment, subretinal bleed, and lipid exudation is the clinical hallmark of PCV. ${ }^{1}$ Features typical of PCV found in our study in decreased frequency were lipid exudation, serous PED, large PED, subretinal bleed, subretinal nodule, and massive submacular haemorrhage.

Soft drusen were only noted in one affected and two fellow eyes, indicating that they are relatively rare in PCV. This finding is supported by another study. ${ }^{5}$ There was only one eye affected by an ipsilateral non-disciform macular scar in the confirmed PCV patients. Disciform scarring is believed to be uncommon in PCV. ${ }^{17}$ Poor vision in our patients was mainly caused by massive submacular haemorrhage and exudation involving the macula. 
PCV is thought to be a bilateral disease, with the fellow eye eventually developing similar lesions. ${ }^{18}$ Our study failed to reveal bilaterality as all our patients had unilateral disease. This may be attributed to the small sample size of our study.

The retinal manifestations of PCV observed in our study were like those of AMD patients; this is supported by other previously published studies. ${ }^{4}$ It was no surprise that six patients in our study were eventually diagnosed with exudative AMD. PCV is regarded as having a low incidence of subretinal fibrovascular proliferation and known to progress slowly. ${ }^{19}$ These factors confer a more favourable visual prognosis compared to exudative AMD patients. It is vital to distinguish PCV from AMD as there are significant differences in the patients' profile, natural course, treatment, and visual outcome. High index of suspicion is required when neovascular AMD patients do not respond well to anti-vascular endothelial growth factor injections, as they might have been misdiagnosed or there may be coexisting PCV. ${ }^{20}$

One non-PCV patient presented with multiple intraretinal haemorrhages associated with macular oedema and a scar. Clinically, it was consistent with exudative AMD. A diagnosis of RAP, a form of CNV, was finally made. RAP lesions are sometimes seen as focal areas of hyperfluorescence or "hot spots" on ICGA, and during the mid and late phases, these lesions become markedly hyperfluorescent as the dye leaks into the intraretinal spaces. ${ }^{21}$ In this patient, the abnormal retinal vessel was seen to turn sharply into the choroid. However, there was no hot spot or leakage noted.

One patient was observed to have features of chronic CSCR. Usually, the diagnosis of CSCR can be made with little difficulty. Patients are typically adults with "type-A" behaviour pattern, presenting with an exudative detachment of the neurosensory retina, frequently with associated multiple serous PEDs and patches of RPE atrophy. ${ }^{22}$ However, with prolonged exudation, as in this case, a variety of RPE changes can develop that may lead to establishing the correct diagnosis a bit tricky. Moreover, there have been reports of macular variants of PCV with similar clinical and FFA features resembling CSCR..$^{17,23}$ In our patient, ICGA ruled out PCV, while FFA demonstrated pinpoint leaks confirming CSCR.

All the previously mentioned cases emphasize the fact that other macular disorders can mimic PCV. Accurate diagnosis is thus imperative for patients to be optimally managed.

In this study, the size of PCV lesions measured as the GLD ranged from 223 to $3625 \mu \mathrm{m}$, with an average mean of $1461.4 \pm 864.41 \mu \mathrm{m}$. The smallest value of 223 $\mu \mathrm{m}$ corresponded to an individual polyp without any BVN, while the largest value of $3625 \mu \mathrm{m}$ corresponded to an extrafoveal cluster of polyps with extensive BVN complex. With such a large area involved, it was expected that this patient's BCVA would be poor. Surprisingly enough, it was good at $6 / 12$ due to resolving subretinal fluid. There was no ICGA leakage, but leakage was evident on FFA. It is imperative to treat this lesion as clinically active. If left untreated, it tends to recur and thus 
carries a worse visual prognosis.

The main location for PCV lesions observed in our study was the extrafoveal area. This finding is similar to that of a study conducted by Cackett on Chinese patients affected by PCV in Singapore. ${ }^{24}$ The most frequently noted formation was cluster, followed by single. Uyama et al. reported that grape-like clusters of polyps were associated with marked haemorrhage and leakage, with subsequent severe visual loss. ${ }^{25}$ PCV lesions in this study were found to involve more single discrete areas than multiple areas. This may be translated further to less aggressive treatment required and potentially good visual outcome.

Polyp pulsation was detected in six eyes. The presence of typical subretinal nodular hyperfluorescence when viewed stereoscopically in our study was noted in only seven eyes (28\%), as compared to over $80 \%$ in definite PCV eyes. ${ }^{1}$ Perhaps the imaging technique used was inferior to the other study. BVN was elucidated in only 14 eyes (56\%). Our detection rate was lower compared to $75 \%$ of demonstrated BVN in a previous study. ${ }^{1}$ Our finding has to be taken into consideration in the determination of laser treatment spot size used for photodynamic therapy (PDT) as initial treatment is usually targeted towards covering the polyp and its associated BVN complex. Failure to incorporate the BVN during PDT may result in persistent or recurrent leakage, thus affecting the visual prognosis.

In our study, $60 \%$ of polyps were observed to have a hypofluorescent halo, which is thought to arise from an active polyp. No hyperfluorescent ring was documented in this study. This may be due to inadequate staining of the polyp wall, thus affecting detection of the ring.

LGH was documented in $28 \%$ of patients. Kang et al. reported that persistence of LGH after PDT was associated with polyp recurrence. ${ }^{26}$ All of our patients were treatment-naïve. Hence, this finding may represent another important angiographic manifestation of PCV lesions. If this holds true, then it is crucial to include the area of LGH in the determination of laser treatment spot size during PDT, so that recurrence can be avoided.

One publication reported that eyes with cluster of grape-like polyps had an increased risk of severe visual loss. ${ }^{25}$ Other authors have hypothesized that eyes with larger sizes of PCV lesions and involvement of multiple areas carry a poor prognosis. ${ }^{1}$

Some authorities consider that PCV is a variant of neovascular AMD, and smoking has been well implicated in the pathogenesis of the latter disease. Smoking may impair choroidal blood flow, and thus promote ischaemia, hypoxia, and micro-infarctions. All these can cause increased susceptibility of the macula to oxidative damages and degenerative changes. ${ }^{30}$ However, we were unable to establish an association between smoking and PCV due to the small sample size.

Knowledge of the characteristics of PCV is vital for proper diagnosis and precise management of this peculiar disease. It is fundamental for the ICGA differences of PCV to be delineated, as this might prove useful as a prognostic indicator. Since this 
study was previously conducted when PCV was a relatively new ocular disease and with the introduction of new terminology such as ICC to describe the disease, we decided to review the angiographic findings again and attempted to correlate the FFA and ICGA findings.

A Japanese study by Maruko et al. found that $11.3 \%$ of 203 eyes with PCV showed classic CNV lesions. ${ }^{5}$ In these cases, $1.5 \%$, 9.8\%, and $88.7 \%$ had predominantly classic CNV, minimally classic CNV and occult CNV, respectively. ${ }^{5}$ Most of their patients had minimally classic or occult CNV on FFA, which is similar to our findings. Occult CNV or type $1 \mathrm{CNV}$ neovascular complex is mainly found below the RPE. Hence, occult CNV is commonly seen in PCV cases. One patient from our study cohort showed pure classic CNV appearance on FFA. Tamura et al. studied PCV eyes with classic CNV and found that the presence of classic CNV could be due to the presence of type $2 \mathrm{CNV}$ or pure fibrinous subretinal material seen on OCT. ${ }^{29}$ Leaking polypoidal lesions potentially lead to subretinal fibrinous exudation, which could also mimic classic CNV picture in FFA. Among PCV eyes with classic CNV, visual prognosis was found to be poorer. ${ }^{29}$

Tan et al. classified the ICGA lesions of PCV into 3 subtypes: type A, B, and C. In type A lesions, polyps were supplied by ICC, whereas type $B$ and $C$ lesions typically show a BVN that exhibits unidirectional blood flow from a specific point towards the polyps. The differentiating feature between these two lesions is the presence of late leakage in FFA for type C PCV. ${ }^{17}$ This classification has become a useful tool for prognostication of PCV eyes. Type A lesions have the best visual outcome among the three subtypes, while type $C$ lesions have the highest rate of moderate visual loss at 5 years. ${ }^{17,31}$ It was reported that $53.3 \%(n=26)$ of eyes in their Singapore cohort showed type C PCV vascular subtypes. ${ }^{17}$ Type A and B subtypes were $22.4 \%$ $(n=24)$ and $24.3 \%(n=26)$, respectively. ${ }^{17}$ Contrarily, EVEREST study I demonstrated that type B PCV was a predominant feature in ICGA with $50 \%(n=27) .{ }^{31}$ Fifteen percent $(n=8)$ had type A while $35.2 \%(n=19)$ had type C lesions. ${ }^{31}$ In our study, 14 (56\%) patients showed BVN on their ICGA; eight (57.1\%) out of these 14 eyes with BVN demonstrated late leakage on FFA. Our study was a descriptive cross-sectional study, therefore we were unable to demonstrate visual acuity changes over time. A longitudinal prospective study is needed to determine the association between visual acuity loss and BVN with late leakage.

The main drawback of this study is its small sample size. Other ethnic groups such as Malays and Indians were not well represented, which can lead to potential bias. OCT findings were not included in the analysis. Also, given the duration available for the study, we were unable to review the visual acuity outcome of the patients after a number of years in order to correlate with the clinical and angiographic findings. This should be the subject of future studies.

Knowledge of the characteristics of PCV is vital for the proper diagnosis and precise management of this peculiar disease. It is fundamental for the ICGA differences of PCV to be delineated, as this might prove useful as a prognostic 
indicator. In conclusion, the diagnosis of PCV can be made with a high level of certainty when the clinical hallmark features of this disease are present. ICGA is the gold standard in clinching the correct diagnosis. Nevertheless, it must be borne in mind that other acquired macular diseases such as exudative AMD and CSCR may present as PCV, thus complicating the diagnosis and raising the possibility of erroneous treatment. The demographic, clinical and angiographic features observed in this study are in accordance with other previously published Asian studies. However, this study did not demonstrate an association between the morphological characteristics of PCV, namely, the size of lesions, location, formation, and number of discrete areas involved, with BCVA.

\section{Declarations}

\section{Ethics approval and consent to participate}

Ethics approval from the Research and Ethics Committee, Faculty of Medicine, University Kebangsaan Malaysia (FF-156-2012) and National Medical Research Register of the Ministry of Health Malaysia were obtained prior to commencement of the study. The study followed the guidelines set in the Malaysian Good Clinical Practice (2nd edition, January 2004) and was conducted in accordance to the principles of the Declaration of Helsinki.

\section{Competing interests}

None to declare.

\section{Funding}

This study was funded by a Fundamental Grant from Pusat Perubatan Universiti Kebangsaan Malaysia (FF-156-2012).

\section{Acknowledgments}

My sincerest gratitude to my supervisors, Dr. Wong Hon Seng and Professor Dr. Mae-Lynn Catherine Bastion for their guidance, patience, and encouragement during the preparation of this dissertation. I am grateful and deeply indebted to Associate Professor Dr. Norshamsiah Md. Din, Dr. Hazlita Dato' Mohd Isa, Associate Professor Jemaima Che Hamzah, and all the lecturers in the Department of Ophthalmology, Universiti Kebangsaan Malaysia for their continuous assistance and moral support during my training. I am indebted to Encik Saiful Bahari Yusoff for his assistance with the technical aspects of this dissertation. I am also grateful to Dr. Saharudin Ahmad for his invaluable help with the statistical analysis. A special thank you goes out to Dr. Amelia Lim Lay Suan, Dr. Nooraniah Azmi, and Puan Amalina Saiful Anwar for helping to retrace the images following the reviewers' input and for assistance in reviewing the data. Finally, my sincerest gratitude and 
deepest appreciation goes to my parents, Encik Nasaruddin Arshad and Puan Rohani Ahmad for their love, support, and prayers during my whole training period.

\section{References}

1. Koh A, Lee WK, Chen L-J, Chen S-J, Hashad Y, Kim H, et al. EVEREST study: efficacy and safety of verteporfin photodynamic therapy in combination with ranibizumab or alone versus ranibizumab monotherapy in patients with symptomatic macular polypoidal choroidal vasculopathy. Retina. 2012;32(8):1453-1464.

2. Pauleikhoff D, Löffert D, Spital G, Radermacher M, Dohrmann J, Lommatzsch A, et al. Pigment epithelial detachment in the elderly. Graefes Arch Clin Exp Ophthalmol. 2002;240(7):533-538.

3. Chuah CT. Idiopathic polypoidal choroidal vasculopathy as a cause of a disciform macular scar. Clin Experiment Ophthalmol. 2003;31:163-165.

4. Yannuzzi LA, Wong DW, Sforzolini BS, Goldbaum M, Tang KC, Spaide RF, et al. Polypoidal choroidal vasculopathy and neovascularized age-related macular degeneration. Arch Ophthalmol. 1999;117(11):1503-1510.

5. Maruko I, lida T, Saito M, Nagayama D, Saito K. Clinical characteristics of exudative age-related macular degeneration in Japanese patients. Am J Ophthalmol. 2007;144(1):15-22.

6. Uyama M, Matsubara T, Fukushima I, Matsunaga H, Iwashita K, Nagai Y, et al. Idiopathic polypoidal choroidal vasculopathy in Japanese patients. Arch Ophthalmol. 1999;117(8):1035-1042.

7. Ahuja RM, Stanga PE, Vingerling JR, Reck AC, Bird AC. Polypoidal choroidal vasculopathy in exudative and haemorrhagic pigment epithelial detachments. Br J Ophthalmol. 2000;84(5):479-484.

8. Lafaut B, Leys A, Snyers B, Rasquin F, De Laey JJ. Polypoidal choroidal vasculopathy in Caucasians. Graefes Arch Clin Exp Ophthalmol. 2000;238(9):752-759.

9. Byeon SH, Lee SC, Oh H-S, Kim SS, Koh HJ, Kwon OW. Incidence and clinical patterns of polypoidal choroidal vasculopathy in Korean patients. Jpn J Ophthalmol. 2008;52(1):57-62.

10. Kwok AKH, Lai TYY, Chan CWN, Neoh E-L, Lam DSC. Polypoidal choroidal vasculopathy in Chinese patients. Br J Ophthalmol. 2002 Aug;86(8):892-7.

11. Wen F, Chen C, Wu D, Li H. Polypoidal choroidal vasculopathy in elderly Chinese patients. Graefes Arch Clin Exp Ophthalmol. 2004;242(8):625-629.

12. Liu Y, Wen F, Huang S, Luo G, Yan H, Sun Z, et al. Subtype lesions of neovascular age-related macular degeneration in Chinese patients. Graefes Arch Clin Exp Ophthalmol. 2007;245(10):1441-1445.

13. Scassellati-Sforzolini B, Mariotti C, Bryan R, Yannuzzi LA, Giuliani M, Giovannini A. Polypoidal choroidal vasculopathy in Italy. Retina. 2001;21(2):121-125.

14. Ladas I, Rouvas A, Moschos M, Synodinos E, Karagiannis D, Koutsandrea C. Polypoidal choroidal vasculopathy and exudative age-related macular degeneration in Greek population. Eye. 2004;18(5):455.

15. Lafaut BA, Aisenbrey S, den Broecke Van C, Bartz-Schmidt K-U, Heimann K. Polypoidal choroidal vasculopathy pattern in age-related macular degeneration: a clinicopathologic correlation. Retina (Philadelphia, Pa). 2000;20(6):650-654. 
16. Macular Photocoagulation Study Group. Subfoveal Neovascular Lesions in Age-related Macular Degeneration. Guidelines for evaluation and treatment in the Macular Photocoagulation study. Arch Ophthalmol. 1991;109:1242-1257.

17. Tan CS, Ngo WK, Lim LW et al. A novel classification of the vascular patterns of polypoidal choroidal vasculopathy and its relation to clinical outcomes. Br J Ophthalmol. 2014;98:1528-1533.

18. Kementerian Kesihatan Malaysia. Age-related macular degeneration, guidelines for management with anti-VEGF therapy in MOH hospitals. 2010.

19. Yannuzzi LA, Ciardella A, Spaide RF, Rabb M, Freund KB, Orlock DA. The expanding clinical spectrum of idiopathic polypoidal choroidal vasculopathy. Arch Ophthalmol. 1997;115(4):478-485.

20. Bird AC, Bressler NM, Bressler SB, Chisholm IH, Coscas G, Davis MD, et al. An international classification and grading system for age-related maculopathy and age-related macular degeneration. The International ARM Epidemiological Study Group. Surv Ophthalmol. 1995 Apr;39(5):367-74.

21. Sho K, Takahashi K, Yamada H, Wada M, Nagai Y, Otsuji T, et al. Polypoidal choroidal vasculopathy: incidence, demographic features, and clinical characteristics. Arch Ophthalmol. 2003;121(10):13921396.

22. Koh AH, Chen L-J, Chen S-J, Chen Y, Giridhar A, lida T, et al. Polypoidal choroidal vasculopathy: evidence-based guidelines for clinical diagnosis and treatment. Retina. 2013;33(4):686-716.

23. Ciardella AP, Donsoff IM, Huang SJ, Costa DL, Yannuzzi LA. Polypoidal choroidal vasculopathy. Surv Ophthalmol. 2004;49(1):25-37.

24. Yannuzzi LA, Freund KB, Goldbaum M, Scassellati-Sforzolini B, Guyer DR, Spaide RF, et al. Polypoidal choroidal vasculopathy masquerading as central serous chorioretinopathy. Ophthalmology. 2000;107(4):767-777.

25. Moorthy RS, Lyon AT, Rabb MF, Spaide RF, Yannuzzi LA, Jampol LM. Idiopathic polypoidal choroidal vasculopathy of the macula. Ophthalmology. 1998;105(8):1380-1385.

26. Cackett P, Wong D, Yeo I. A classification system for polypoidal choroidal vasculopathy. Retina. 2009;29(2):187-191.

27. Uyama M, Wada M, Nagai Y, Matsubara T, Matsunaga H, Fukushima I, et al. Polypoidal choroidal vasculopathy: natural history. Am J Ophthalmol. 2002;133(5):639-648.

28. Fernandes LHS, Freund KB, Yannuzzi LA, Spaide RF, Huang SJ, Slakter JS, et al. The nature of focal areas of hyperfluorescence or 'hot spots' imaged with indocyanine green angiography. Retina. 2002;22(5):557-568.

29. Tamura H, Tsujikawa A, Otani A, Gotoh N, Sasahara M, Kameda T, Iwama D, Yodoi Y, Mandai M, Yoshimura N. Polypoidal choroidal vasculopathy appearing as classic choroidal neovascularisation on fluorescein angiography. Br J Ophthalmol. 2007 Sep 1;91(9):1152-9.

30. Kang SW, Chung SE, Shin WJ, Lee J-H. Polypoidal choroidal vasculopathy and late geographic hyperfluorescence on indocyanine green angiography. Br J Ophthalmol. 2009;93(6):759-76.

31. Tan CS, Lim LW, Ngo WK, Lim TH. EVEREST report 5: clinical outcomes and treatment response of polypoidal choroidal vasculopathy subtypes in a multicenter, randomized controlled trial. Invest Ophthalmol Vis Sci. 2018 Feb 1;59(2):89-96. 